\title{
Orijentacijsko globe natjecanje - važan motivacijski čimbenik u implementaciji Programa GLOBE
}

\author{
Diana Garašić \\ Nova Ves, Zagreb, Hrvatska, ORCID: 0000-0002-6489-2031 \\ diana.garasic@gmail.com
}

\begin{abstract}
SAŽETAK
Program GLOBE je međunarodni, znanstveno-obrazovni program koji se u Republici Hrvatskoj ostvaruje od 1995. godine na temelju međudržavnog sporazuma. Škole u programu obavljaju mjerenja i opažanja u svojem okolišu, u području atmosfere, tla, vode i pokrova, a rezultate upisuju u jedinstvenu svjetsku bazu podataka. Program predviđa svakodnevna atmosferska mjerenja te povremene izlaske učenika na terensku nastavu radi mjerenja i opažanja u području istraživanja vode, tla i pokrova. Suvremenost obrazovne komponente u primjeni ovog programa prepoznaje se sljedećim značajkama: interdisciplinarnost, iskustveno učenje, praktičan rad i terenska nastava, korištenje suvremene tehnologije. Sve to, uz timski rad i vještinu orijentacije u prostoru promiče Orijentacijsko GLOBE natjecanje u sklopu godišnjih susreta GLOBE škola. Ti susreti predstavljaju mogućnost okupljanja, povezivanja i razmjene iskustva učenika i nastavnika i dokazalo se, tijekom 22 godine provedbe kao značajan motivacijski čimbenik za provedbu Programa GLOBE u školama.
\end{abstract}

Ključne riječi: orijentacijsko natjecanje; interdisciplinarnost; timski rad; motivacija

\section{UVOD}

Implementacija Programa GLOBE započela je u Republici Hrvatskoj u travnju 1995. godine na temelju potpisanog Sporazuma između predstavnika hrvatske vlade i predstavnika nositelja programa iz SADa. Sporazum je dostupan na internetskim stranicama hrvatskog programa GLOBE (Program GLOBE Hrvatska, 2018).

Naziv programa je akronim i u prijevodu glasi Globalno ili cjelovito učenje i opažanje za dobrobit okoliša (Global Learning and Observations to Benefith the Environment). Program je zamišljen kao suradnja znanstvenika i škola diljem svijeta, koja se ostvaruje komunikacijom putem interneta (Leidner i sur, 1994). Znanstvenici su osmislili protokole za mjerenja u području atmosfere, vode, tla i pokrova te $u$ području Zemlja kao sustav (Panec i sur, 2005). Ti postupci mjerenja i opažanja znanstveno su korektni i velikim dijelom utemeljeni u postojećoj znanstveno-istraživačkoj praksi, a u neposrednoj su provedbi prilagođeni kako bi načinom primjene i cijenom opreme bili pristupačni školama. GLOBE škole provode monitoring svojeg okoliša, u opsegu koji same odaberu, koristeći propisane protokole i mjernu opremu određenih specifikacija. Na taj se način prikupljaju međusobno usporedivi podaci, koji se putem interneta upisuju u jedinstvenu GLOBE bazu podataka (Sparrow i sur, 2015). Sakupljeni podaci su javno dostupni pa ih mogu koristiti znanstvenici za svoja istraživanja, škole za obrazovne potrebe, ali i u izradi učeničkih istraživačkih projekata i svi drugi posjetitelji internetskih stranica Programa GLOBE.

Hrvatski Nacionalni kurikulum, u okviru predmetnih kurikuluma uz odgojno-obrazovne ishode propisuje i sadržaje (MZO, 2018). Stoga nije moguće Program GLOBE u cijelosti provoditi u sklopu redovite nastave pa se on uglavnom provodi kao izvannastavna aktivnost. Ipak, u skladu s aktualnim kurikulumom, neki se dijelovi Programa GLOBE mogu, mnogo uspješnije nego ranije uklopiti u nastavu različitih predmeta, posebno u predmete prirodoslovlja, geografiju te informatiku (Program GLOBE Hrvatska, 2020b). 
U hrvatskom modelu implementacije od samih se početaka škole potiču na korištenje GLOBE baze podataka u nastavi različitih predmeta, što doprinosi boljem razumijevanju gradiva u smislu potkrepljivanja teorijskih znanja. U svojem istraživanju Manduca i Mogk (2002) utvrđuju da učenici uspješnije povezuju svoje, lokalno prikupljene podatke s podacima koji opisuju Zemlju kao sustav ako imaju pristup podacima škola iz cijelog svijeta, kao i pristup rezultatima provedenih daljinskih istraživanja s pomoću satelita (slika 1).

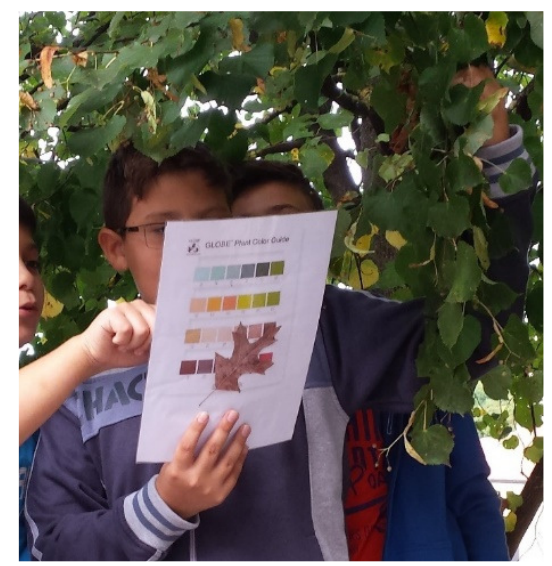

Slika 1 Fenološka opažanja uz praćenje promjena boje listova (izvor: www.globe.gov)

Hrvatske su se školske ekipe tijekom godina usavršavale u izradi istraživačkih projekata na temelju rezultata GLOBE mjerenja i opažanja pa su mnoge od njih sudjelovale u međunarodnim projektima, osvojile priznanja na međunarodnim GLOBE smotrama, a ponajviše na nacionalnoj smotri istraživačkih projekata u sklopu Smotri i natjecanja hrvatskih GLOBE škola (AZOO, 2020a).

U ovom se radu pozornost usmjerava na razvoj ideje i provedbu specifičnog hrvatskog modela GLOBE natjecanja (Garašić, 2019).

\section{ORIJENTACIJSKO GLOBE NATJECANJE}

Ubrzo nakon što su 1996. godine prve škole počele ostvarivati Program GLOBE, postalo je jasno da je on vremenski i organizacijski prilično zahtjevan za provedbu. To se ponajprije odnosi na područje meteorologije koje iziskuje svakodnevna mjerenja i opažanja i to u vremenskom intervalu od maksimalno 1 sat prije ili nakon solarnog podneva (The Program GLOBE, 2020b). Tu se pojavljuje problem izlaska s nastave zaduženih učenika, koji bi trebali obaviti mjerenja kod školske meteorološke kućice, ali i problem obavljanja meteoroloških mjerenja tijekom vikenda i praznika. Nadalje, terenska mjerenja u području vode, tla i pokrova povremeno zahtijevaju organizirani izlazak učenika izvan škole, u trajanju od najmanje jedan sat, a često i više, ovisno o udaljenosti mjernih mjesta.

U prvim godinama provedbe nastavnici su izvještavali i o problemu pristupa računalu na internetu, što nije bilo moguće u svakom trenutku jer je oprema u većini škola bila vrlo skromna, a pristup internetu ograničen. Tek od 2000. godine počinje sustavna informatizacija hrvatskih škola (Kiseljak, 2019), a usporedno su se organiziranim stručnim usavršavanjem te informalnim učenjem unapređivale informatičke kompetencije nastavnika. Sve je to, s ulaskom u 21. stoljeće značajno olakšalo provedbu programa GLOBE.

Valja naglasiti da su sadržaji Programa GLOBE interdisciplinarni, odnosno multidisciplinarni, što zahtijeva suradnju nastavnika različitih stručnih profila. U školama gdje su zaduženja u provedbi programa raspoređena između više nastavnika, a posebno tamo gdje postoji nedvojbena podrška 
ravnatelja, svi su se opisani problemi nekako uspijevali nadići. Štoviše, nekoliko je hrvatskih škola u prvim godinama provedbe bilo u samom vrhu svjetske ljestvice poretka GLOBE škola prema broju prikupljenih podataka. Tu svakako treba spomenuti Osnovnu školu Konjščina, iz malog mjesta na području Krapinsko-zagorske županije, koja je tijekom više godina prema broju prikupljenih podataka bila među prvih 10 škola u cijelome svijetu, a sve zahvaljujući motiviranim nastavnicima i bezrezervnoj podršci ravnatelja. Mnogo je teže kad je samo jedan nastavnik u školi zadužen za provedbu ovog programa, posebno ako nema odgovarajuću podršku vodstva škole. Upravo se to dogodilo i u OŠ Konjščina nakon odlaska dotadašnjeg ravnatelja u mirovinu pa je cjelokupna aktivnost opteretila samo jednu učiteljicu, što je dovelo do zasićenja i konačno do obustavljanja provedbe Programa GLOBE. Odustajanje škole, nakon razdoblja aktivnosti, pokazalo se kao česta posljedica upravo preopterećenosti nastavnika i nedostatne potpore od strane kolega i vodstva škole. Posljedica pretjeranog opterećenja jednog nastavnika može se očitovati i kao opadanje kvalitete provedbe programa u smislu redovitosti, točnosti i opsega mjerenja, a posebno u radu s učenicima, kontroliranju korektnosti njihovih postupaka, točnosti rezultata mjerenja, unosa te zajedničkog analiziranja prikupljenih podataka. Nažalost, u takvim slučajevima izostaje i korištenje GLOBE baze podataka, radi usporedbe s vlastitim podacima ili usporedbe podataka za različite parametre u različitim dijelovima svijeta. Zbog toga se ne koristi puni potencijal Programa GLOBE u razvijanju prirodoslovne pismenosti.

Navedeni problemi nisu hrvatska specifičnost, već su se pojavljivali i u drugim zemljama, čak i onima čije su škole dobro opremljene i s otvorenim kurikulumom (Previšić, 2007, Berlinsky-Schine, 2018), koji dozvoljava da se u GLOBE aktivnosti tijekom dužeg razdoblja uključi cijeli razredni odjel te da provedba ne iziskuje dodatno vrijeme izvan redovite nastave. Nakon uvođenja Kurikuluma u prirodoslovnim predmetima (MZO, 2018) moguća je provedba nekih dijelova programa GLOBE s cijelim razrednim odjelom, kao na primjer u Prirodi 5. razreda, gdje se predviđa praćenje promjena svojstava vode, zraka i tla tijekom godišnjih doba te u 6 . razredu Prirode, gdje se predviđaju fenološka opažanja i mjerenja u cilju razumijevanja ciklusa u prirodi.

Osposobljavanje nastavnika za provedbu Programa GLOBE organizirala je Agencija za odgoj i obrazovanje (prije Zavod za školstvo) od 1996. redovito, jednom do dva puta godišnje. Sudionici tih skupova mahom su bili vrlo zadovoljni stečenim znanjima i vještinama te motivirani za provedbu programa s učenicima. Međutim, suočeni u praksi s naprijed opisanim teškoćama i ograničenjima, koja često nisu znali ili mogli savladati, njihova bi motiviranost slabila. Kao što je već navedeno, neke su škole uspijevale rješavati zapreke uspješnije nego druge pa je postala razvidna važnosti i vrijednosti međusobnih susreta nastavnika i ravnatelja, radi razmijene ideja i primjera uspješne prakse. Od samih je sudionika potekla ideja kako bi dobro bilo u takve susrete GLOBE sudionika uključiti i učenike. Postojeći organizacijski model u hrvatskom školskom sustavu koji bi to omogućio bila je smotra ili natjecanje. Tako je godine 1998. GLOBE natjecanje uvršteno u Nacionalni sustav natjecanja i smotri pod nazivom Prvi susret hrvatskih GLOBE škola. Naziv Susret najbolje je korespondirao s osnovnom idejom i ciljem okupljanja GLOBE sudionika (AZOO, 2021c), ponajprije radi međusobnog upoznavanja i povezivanja u zajedničkim istraživačkim aktivnostima, razmjene iskustava i motivacije. Uvrštenjem Susreta GLOBE škola u nacionalni sustav natjecanja i smotri osigurana je i financijska potpora Ministarstva znanosti i obrazovanja, za potrebe prijevoza i smještaja sudionika.

Prvi susret hrvatskih GLOBE škola održan je pod pokroviteljstvom Predsjednika Republike dr. Franje Tuđmana, a domaćin je bio Grad Zagreb i OŠ Nikole Tesle (slika 2). 


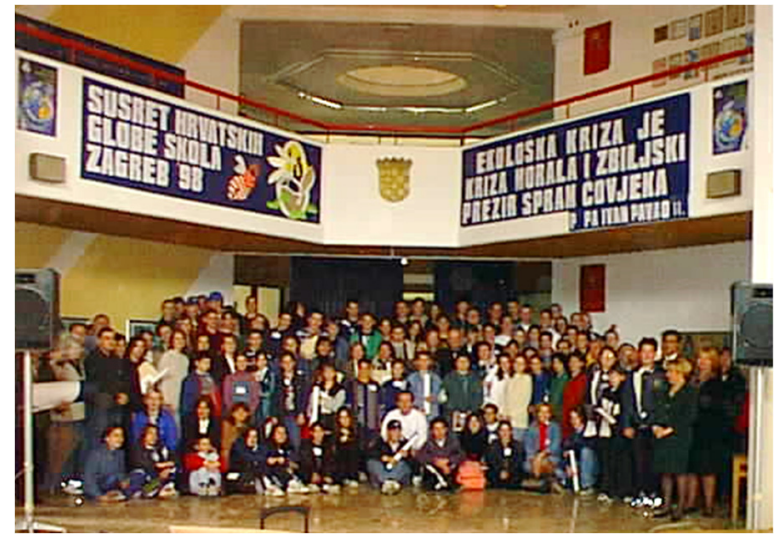

Slika 2 Prvi susret hrvatskih GLOBE škola, 1998. (autor fotografije: Zlatan Soldo)

GLOBE program je globalna suradnička mreža pa se međusobno natjecanje sudionika ne uklapa najbolje u tu osnovnu ideju. Sudjelovanje u natjecanju najčešće je potaknuto težnjom za priznanjem ili nekim vidom nagrade (Vallerand et all, 2010). S druge strane, očekivalo bi se da je sudjelovanje u programu kojim se ostvaruje dobrobit za znanost, za okoliš, za živi svijet i buduće generacije, potaknuto težnjom da se čini dobro pa sama ta činjenica predstavlja nagradu ili potkrjepljenje. Ipak je prevagnula ocjena da bi okupljanje sudionika iz GLOBE škola u obliku natjecanja moglo bitno pridonijeti motivaciji uključenih učenika i nastavnika pa je osmišljen program trodnevnog Susreta GLOBE sudionika, koji je obuhvatio predstavljanje školskih ekipa, prezentacije ostvarivanja Programa GLOBE u svakoj od škola, ekipno orijentacijsko natjecanje te vođeno upoznavanje kroz rekreativni program. U prvim godinama provedbe, iza Domovinskog rata okupljanje GLOBE sudionika ne bi bilo moguće da nije bilo financirano od strane Ministarstva. Stoga je GLOBE natjecanje trebalo osmisliti tako da zadovolji standarde nacionalnog sustava natjecanja, ali i specifične ciljeve koji proizlaze iz samog programa i prihvaćenog modela njegove implementacije. Ti su ciljevi ugrađeni u koncepciju u svijetu jedinstvenog hrvatskog modela GLOBE natjecanja:

s ciljem poticanja timskog rada, suradničkog učenja i rješavanja problema (Rutheford, 2014), svaku školu predstavlja tročlana učenička ekipa, koja zajednički rješava zadatke natjecanja;

s ciljem razvijanja vještina orijentacije u prostoru uz pomoć karte, natjecanje je orijentacijsko, što znači da ekipa mora pronaći zadane točke na nepoznatom terenu;

zadaci trebaju biti teorijski i praktični, a obuhvaćaju poznavanje i razumijevanje GLOBE protokola, primjenu vještina potrebnih za izvođenje mjerenja i opažanja te razumijevanje značenja prikupljenih podataka.

zadaci trebaju obuhvatiti postupke za unos podataka te poznavanje sadržaja Programa GLOBE i alata za prikazivanje i interpretaciju vizualizacija izrađenih na temelju GLOBE podataka.

Mnogi učenici koji su tijekom pohađanja osnovne ili srednje škole sudjelovali u Programu GLOBE željeli su ostati s njim povezani i nakon završetka škole. Njima se nudi mogućnost uključivanja u međunarodnu grupu GLOBE Alumni, u kojoj mogu i dalje surađivati kao pomagači u svojoj školi i lokalnoj zajednici te promovirati GLOBE program. Krajem 2019. godine provedena je anketa među članovima te grupe bivših GLOBE učenika. Između ostaloga, pitalo ih se koji je aspekt Programa GLOBE na njih ostavio najsnažniji dojam. Većina od 15 ispitanika navela je GLOBE smotru i natjecanje. Objasnili su to manjim pritiskom od onoga što doživljavaju na drugim natjecanjima, olakšavajućom okolnošću timskog rješavanja zadataka, zanimljivošću zadataka, kombinacijom znanja, vještina orijentacije $\mathrm{i}$ fizičke spremnosti, a ponajprije druženjem i upoznavanjem vršnjaka iz drugih krajeva Hrvatske. 
Na državnoj smotri i natjecanju hrvatskih GLOBE škola obično sudjeluje oko 40 školskih ekipa, odnosno oko 120 učenika i 40 mentora. Odnos broja osnovnih i srednjih škola je 60 \% OŠ : 40 \% SŠ, što je proporcionalno ukupnom broju uključenih škola u Program GLOBE iz svake od tih razina.

U orijentacijskom GLOBE natjecanju školske ekipe trebaju pokazati interdisciplinarno znanje, vještine pri korištenju pribora za mjerenja i opažanja, vještine korištenja GLOBE baze podataka, ali i fizičku spremnost i timsku uigranost. GLOBE orijentacijsko natjecanje proizlazi iz usmjerenosti na terenski i praktičan rad, što odgovara zahtjevima suvremenog obrazovanja (Fägerstam, 2013).

Tijekom godina došlo je do smanjivanja broja kategorija u nacionalnom sustavu natjecanja i smotri, pa je od 2004. godine Susret GLOBE škola preimenovan u Smotru i natjecanje hrvatskih GLOBE škola (AZOO,2021b). Na temelju definiranih ciljeva, oblikovana su Pravila za GLOBE natjecanje, koja su dostupna na Internetskim stranicama hrvatskog Programa GLOBE (AZOO, 2020c), a koja se u osnovi nisu mijenjala sve do danas.

Stazu orijentacijskog natjecanja, u suradnji s državnim koordinatorom, predsjednikom i/ili tajnikom državnog povjerenstva postavlja škola domaćin. Da bi se izbjegao sukob interesa, ekipa škole domaćina ne sudjeluje u natjecanju, budući da sudjeluje u njegovoj pripremi. Učenici domaćina stoga imaju različita dežurstva i zaduženje tijekom natjecanja i cijelog susreta.

Na stazi orijentacijskog natjecanja postavljaju se start i cilj, između kojih je pet do šest kontrolnih točaka. Na svakoj od njih dežuraju članovi državnog povjerenstva i učenici škole domaćina (slika 3).

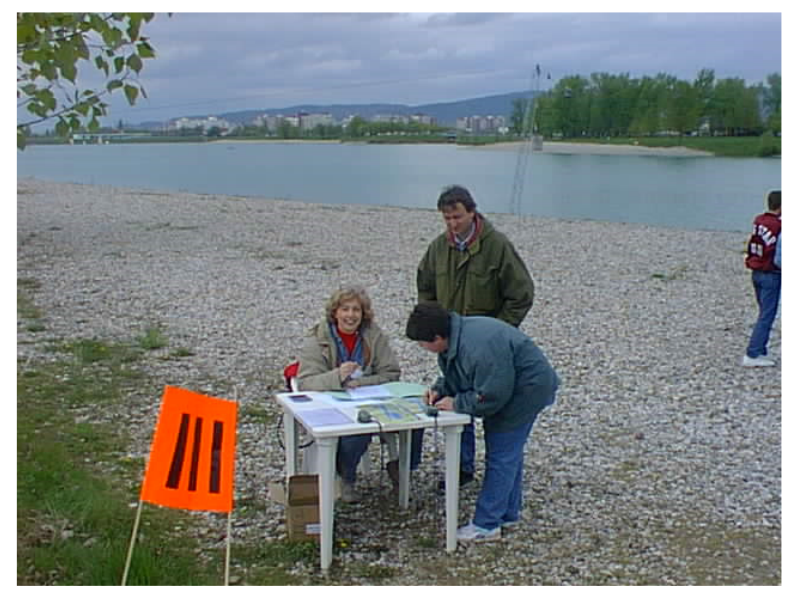

Slika 3 Kontrolori na jednoj od kontrolnih točaka čekaju dolazak natjecateljskih ekipa (autor fotografije: D. Garašić)

Natjecatelji na startu dobiju kartu s označenim kontrolnim točkama i ciljem (Prilg 1). Interaktivne karta GLOBE natjecanja za osnovne i srednje škole održanog u Ninu 2013., na kojoj se klikom otvaraju zadaci uz svaku kontrolnu točku najbolje ilustrira provjeru znanja i vještina učenika sudjelovanjem u orijentacijskom GLOBE natjecanju (GLOBE Hrvatska, 2013).

Na kontrolnim točkama, koje moraju obići po redu, ekipe dobiju na uvid zadatke u pisanoj formi, a na nekim je točkama postavljen i praktični zadatak (slika 4 i 5). 


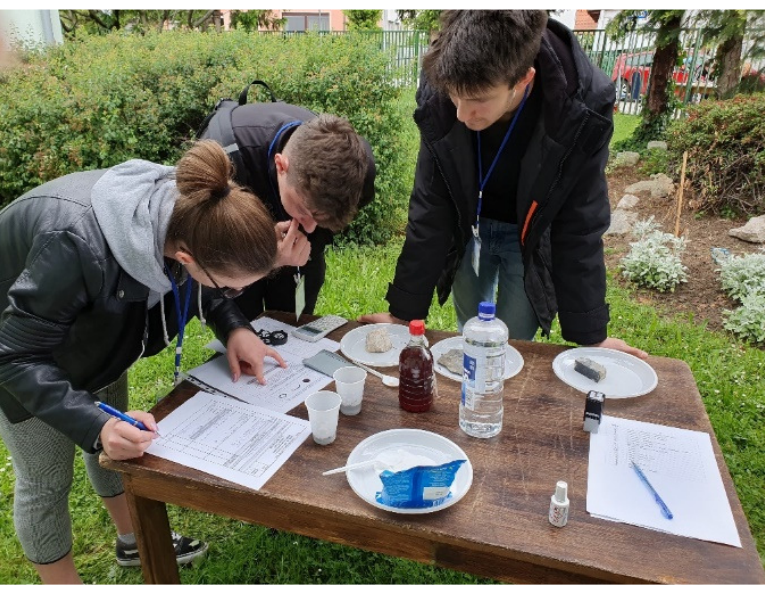

Slika 4 Tročlana učenička ekipa na kontrolnoj točki rješava praktični zadatak primjenom GLOBE protokola za određivanje svojstava tla (autor fotografije: D. Garašić)

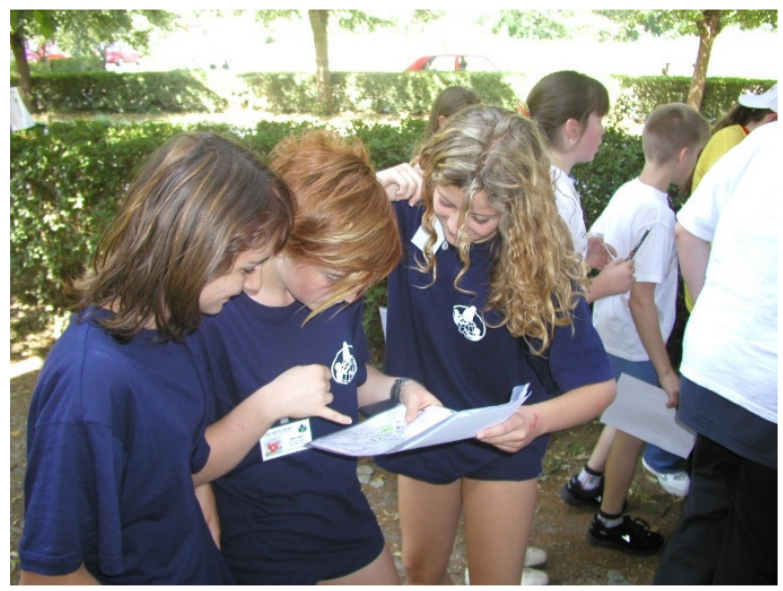

Slika 5 Ekipe timski rješavaju zadatke unoseći rješenja u zajednički radni list (autor fotografije: D. Garašić)

Na cilju ekipe predaju svoj radni list s odgovorima, a kontrolori zabilježe vrijeme kad je pristigao i posljednji član ekipe. Rezultat ekipe izračunava se kao zbroj bodova za točne odgovore i bodova za brzinu prolaska staze u omjeru $80 \%: 20 \%$. U počecima natjecanja omjer je bio $60 \%: 40 \%$ u korist znanja, no s godinama se udio bodova za znanje povećao. Razlog toj izmjeni omjera bodova bio je $u$ namjeri da se učeničke ekipe odvrati od brzog i neopreznog trčanja po neravnom terenu. $U$ želji da osvoje bodove za ostvareno vrijeme, učeničke su ekipe obraćale više pozornosti na brzinu, a zadatke su rješavale površno i bez zadubljivanja. Ostvareno vrijeme na cilju i dalje igra važnu ulogu jer brzina prolaska staze, osim fizičke spremnosti ekipe, pokazuje i vještinu snalaženja u prostoru. No, brzo trčanje više nije dominantna vještina i učenici smirenije pristupaju promišljanju o zadacima koje treba riješiti.

Budući da se želi izbjeći gužva na stazi natjecanja (slika 4) te da se učenicima na svakoj kontroli osigura sav potrebni pribor, unaprijed se izvlačenjem određuje redoslijed starta. To znači da se ekipe sa startne točke upućuju na stazu svakih 5 do 10 minuta, ovisno o zahtjevnosti zadataka na kontrolnim točkama. Primjeri nekih zadataka nalaze se u prilogu (Prilog 2).

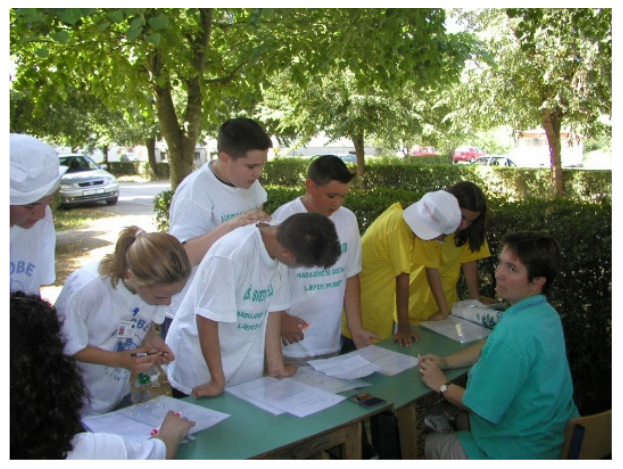

Slika 6 Tri su učeničke ekipe sustigle jedna drugu na istoj kontrolnoj točki, premda su imale različiti startno vrijeme (autor fotografije: D. Garašić)

Načelno se može ustvrditi da učenici bolje rješavaju zadatke vezane uz protokole koje primjenjuju, za razliku od onih koje poznaju samo na temelju proučavanja priručnika i materijala s internetskih stranica. Slično kao i u drugim provjerama znanja, najbolja je riješenost zadataka najnižih razina, koji ispituju reprodukciju činjenica (prepoznavanje, dosjećanje naziva i brojčanih vrijednosti, 
pridruživanje...). Zadaci na razini primjene i rješavanja problema, u pravilu imaju lošiju riješenost. Ipak, posljednjih se godina uvrštava sve više zadataka viših kognitivnih razina, što skreće fokus s provjere poznavanja GLOBE protokola i načina unosa podataka u GLOBE bazu, prema provjeri razumijevanja i primjene prirodoslovnih koncepata te sposobnosti interpretacije podataka.

Startno vrijeme može utjecati na rezultat pojedine ekipe, kao i atmosferski čimbenici. Znalo se dogoditi da kiša prekine natjecanje, da su neke ekipe na stazi ujutro, a druge iza podneva, po vrućini. Stoga se od početka nastojalo učenicima objasniti da na rezultat natjecanja, osim njihova znanja i vještina, može utjecati i sreća i čimbenici u okolišu. Željelo se u život provesti geslo da je važno sudjelovati i dati sve od sebe, a ujedno osvijestiti što su pojedinoj ekipi jake, a što slabije strane, to jest gdje ima prostora za napredovanje. Drugi riječima, GLOBE orijentacijsko natjecanje se u nekim aspektima može usporediti sa sportskim natjecanjima.

Zbog pandemije COVID 19 i obaveze pridržavanja epidemioloških mjera, u studenom 2020. godine održano je po prvi puta on-line natjecanje putem Moodle platforme MOD (SRCE, 2020) na stranici Bioznalac (Radanović i Garašić, 2020). To je bilo posve novo iskustvo i za autore pitanja i za tehničku stranu organizacije i naravno, za same učenike. Kao i na prošlim natjecanjima zadaci su obuhvatili različita GLOBE područja (atmosferu, vodu, tlo, pokrov, poznavanje GLOBE baze podataka i orijentaciju s pomoću karte) (AZOO, 2020d). Zadataka je bilo više nego na dosadašnjim natjecanjima, jer se željela dobiti jasna distribucija bodova, budući da je izostala komponenta stvarnog kretanja i orijentacije u prostoru, kao i komponenta praktičnog rada. Stvarna orijentacija u prostoru nadomještena je zadacima koji su tražili orijentiranje s pomoću topografske karte i vrlo su temeljito ispitali razumijevanje i sposobnost primjene geografskih vještina. Test se rješavao tijekom 90 minuta i sve su učeničke ekipe uspjele dovršiti zadaću u raspoloživom vremenu. Raspon ostvarenih bodova bio je dovoljno velik, što je omogućilo da se jasno razlikuju osvojena mjesta na ukupnoj ljestvici poretka (AZOO, 2020e). Ukoliko se i idućih godina natjecanje bude održavalo online, i praktične se vještine i znanja mogu ispitati analiziranjem snimke pojedinog mjerenja i/ili rezultata mjerenja.

Možda će ovo, u osnovi pozitivno iskustvo biti poticaj za buduće osuvremenjivanje dijela natjecanja putem digitalne platforme, čime se može uštedjeti vrijeme i papir, ali orijentacija u realnom vremenu i prostoru, s kretanjem u prirodi i dalje će ostati temelj i znak raspoznavanja orijentacijskog GLOBE natjecanja, kao specifičnosti u hrvatskom modelu implementacije.

\section{ZAKLUČAK I METODIČKI ZNAČAJ}

Premda natjecanje među sudionicima nije posve u duhu Programa GLOBE koji promovira suradnju i zajedništvo u djelovanju na dobrobit okoliša, u hrvatskom je modelu implementacije ono odigralo značajnu motivacijsku ulogu. Škole koje osvoje pravo sudjelovanja na državnoj razini natjecanja, dobivaju pozitivnu povratnu informaciju o svojem radu, čime se Program GLOBE dodatno afirmira u njihovoj sredini. GLOBE orijentacijsko natjecanje promiče mnoge suvremene strategije učenja $i$ poučavanja: interdisciplinarnost, timski rad u rješavanju problemskih zadataka, praktični rad, iskustveno učenje i izvan učioničku nastavu, a potiče se i ovladavanje životno primjenjivih vještina kao i fizička spremnost sudionika. Natjecanje omogućuje susret nastavnika i učenika, njihovo međusobno upoznavanje i povezivanje u hrvatsku suradničku GLOBE mrežu.

\section{LITERATURA}

AZOO (2020a). Program GLOBE. Dostupno na: https://www.azoo.hr/programi-arhiva/program-globe-ostvaruje-zamisao-misli-globalno-djelujlokalno/, pristupljeno 25.112020. 
AZOO (2020b). Opća pravila za provedbu natjecanja i smotri u školskoj godini 2020/2021. Dostupno na: https://www.azoo.hr/upute-i-obavijesti-arhiva/opca-pravila-za-provedbu-natjecanja-i-smotri-u-skolskoj-godini-2020-2021, pristupljeno 25.112020.

AZOO (2020c). Smotra i natjecanje hrvatskih GLOBE škola 2020. Dostupno na: https://www.azoo.hr/natjecanja-i-smotre-arhiva/smotrai-natjecanje-hrvatskih-globe-skola-2020, pristupljeno 25.112020./

AZOO (2020d). Zadaci s državne Smotre i natjecanja hrvatskih GLOBE škola 2020. Dostupno na: https://www.azoo.hr/natjecanja-ismotre-arhiva/zadaci-s-drzavne-smotre-i-natjecanja-hrvatskih-globe-skola-2020/, pristupljeno 25.112020.

AZOO, (2020e). Rezultati Natjecanja i smotre hrvatskih GLOBE škola 2019.-2020. Dostupno na: https://www.azoo.hr/natjecanja-jsmotre-arhiva/rezultati-natjecanja-i-smotre-hrvatskih-globe-skola-2019-2020/, pristupljeno 25.11.2020.

Berlinsky-Schine, L. (2018): Open Curriculum Schools: 11 Colleges That Allow Students to Direct Their Own Learning. Dostupno na: https://blog.collegevine.com/open-curriculum-schools-11-colleges-that-allow-students-to-direct-their-own-learning/, pristupljeno 12.9.2020.

Radanović I., Garašić D. (2020).Bioznalac. MOD. Dostupno na: https://mod.srce.hr/course/view.php?id=197\&section=1, pristupljeno 25.11.2020.

Fägerstam, E. (2014). High school teachers' experience of the educational potential of outdoor teaching and learning. Journal of Adventure Education \& Outdoor Learning, 14(1), 56-81. Dostupno na: https://www.tandfonline.com/doi/abs/10.1080/14729679.2013.769887, pristupljeno 10.9.2020.

Garašić, D. (2019): GLOBE Student Conference and Competition ("GLOBE Games") in Croatia. Dostupno na: https://www.globe.gov/web/croatia/home/news 09/16/2019, pristupljeno 10.9.2020.

GLOBE Hrvatska (2013). Staza orijentacijskog natjecanja za OŠ sa zadacima i rješenjima po kontrolnim točkama, Staza orijentacijskog natjecanja za SŠ sa zadacima i rješenjima po kontrolnim točkama, XVI. Smotra i natjecanje hrvatskih GLOBE škola, OŠ Zadarski otoci, Zadar, 13. - 15. 5. 2013., GLOBE Hrvatska. Dostupno na: https://globe.pomsk.hr/smotra\%202013/Zadar2013.htm, pristupljeno 14.9.2020.

Kiseljak, G. (2019): Nastava informatike u osnovnim školama, završni rad, Sveučilište u Zagrebu, Filozofski fakultet. Dostupno na: https://repozitorij.ffzg.unizg.hr/islandora/object/ffzg\%3A168/datastream/PDF/view, pristupljeno 10.9.2020.

Leidner, A., Murphy, T., Dallas, L. (1994). The Global Learning and Observations to Benefit the Environment (GLOBE) Program. Dostupno na: https://www.globe.gov/about/history, pristupljeno 15.2.2020.

Manduca, C. A., Mogk, D. W. (2002): Drawing Connections Between Local and Global Observations: An Essential Element of Geoscience Education. Dostupno na: https://ui.adsabs.harvard.edu/abs/2002AGUFMED52C..01M/abstract, pristupljeno 10.9.2020

MZO, 2018 Ministarstvo znanosti i obrazovanja (2018): Nacionalni kurikulum. Dostupno na: https://mzo.gov.hr/istaknuteteme/odgoj-i-obrazovanje/nacionalni-kurikulum/nacionalni-kurikulumi/531, pristupljeno 10.9.2020.

Panec, K., Brooks, D., McLaughlin, J., Seavey, M. M., Grimm, M., Hickman, C., ... Agbese, Q. (2005, May). Teacher, Student, and Scientist Collaboration for the Benefit of Education and Science: GLOBE ONE. In AGU Spring Meeting Abstracts (Vol. 2005, pp. ED12A-04). Dostupno na: https://ui.adsabs.harvard.edu/abs/2005AGUSMED12A..04P/abstract, pristupljeno 10.9.2020.

Previšić, V. (2007). Kurikulum: teorije, metodologija, sadržaj, struktura. Zagreb: Školska knjiga.

Program GLOBE - Hrvatska (20218). O GLOBE programu , Program GLOBE - Hrvatska. Dostupno na: http://globe.hr/o-globeprogramu/, pristupljeno 14.9.2020.

Program GLOBE - Hrvatska (2020a). Smotre i natjecanja, Program GLOBE - Hrvatska. Dostupno na: http://globe.hr/smotre-inatjecanja/, pristupljeno 14.9.2020.

Program GLOBE - Hrvatska (2020b). GLOBE u kurikulumu, Program GLOBE - Hrvatska. Dostupno na: http://globe.hr/globe-ukurikulumu/, pristupljeno 14.9.2020.

Roberts, J.W (2012). Beyond Learning by Doing: Theoretical Currents in Experiential Education, Routledge. Dostupno na: https://books.google.hr/books?hl=hr\&lr=\&id=zJRdBwAAQBAJ\&oi=fnd\&pg=PP1\&dq=learning+by+doing+education\&ots=J2fNgCf1\&sig=kFvQbf kEfeHGQqBntxVRKTptnY\&redir esc=y\#v=onepage\&q=learning\%20by\%20doing\%20education\&f=false, pristupljeno 14.9.2020.

Rutherford, Stephen M., ed. 2014. Collaborative learning: theory, strategies and educational benefits, ORCA, Cardiff University. Dostupno na: http://orca.cf.ac.uk/88584/, pristupljeno 12.9.2020.

Sparrow, E. B., Yule, S., Murphy, A. ur. (2015). Cultivating a Global Pool of Future Geoscientists and Mentors, American Geophysical Union Dostupno na: https://ui.adsabs.harvard.edu/abs/2015AGUFMED23A0857S/abstract, pristupljeno 13.9.2020.

SRCE, 2020. MOD sustav za e-učenje. Dostupno na: https://mod.srce.hr/, https://www.srce.unizg.hr/sustavi-za-ucenje-na-daljinu/mod, pristupljeno 25.11.2020.

The Program GLOBE (2020a). The Program GLOBE. Dostupno na: https://www.globe.gov/, pristupljeno 15.2.2020.

The Program GLOBE (2020b). Protocol e-training/ Atmosphere, The Program GLOBE. Dostupno na: https://www.globe.gov/gettrained/protocol-etraining/etraining-modules/16867642/12267, pristupljeno 10.9.2020.

Vallerand, R. J., Gauvin, L. I., \& Halliwell, W. R. (1986). Negative effects of competition on children's intrinsic motivation. The Journal of Social Psychology, 126(5), 649-656. DOI: https://doi.org/10.1080/00224545.1986.9713638, pristupljeno 3.9.2020. 


\section{PRILOZI}

Prilog 1 Karta orijentacijskog natjecanja za osnovne škole, održanog 2011. godine u Sv. Martinu na Muri

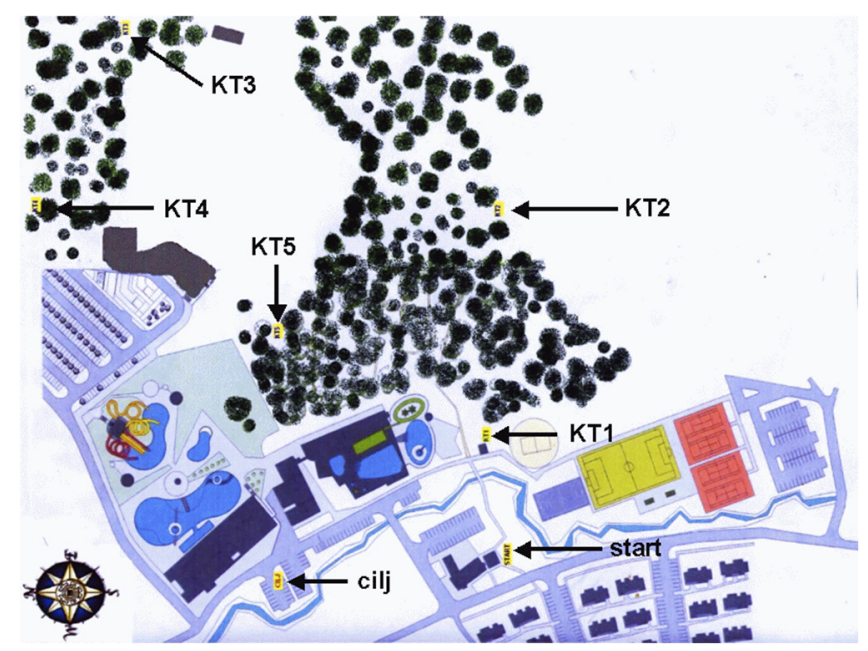

Prilog 2 Primjer zadataka na kontrolnim točkama za osnovnu školu, s natjecanja održanog 2011. u Čakovcu

\section{UPUTE U PRIPREMI ZA START - Osnovne škole}

Orijentacijsko natjecanje predviđa da redom prođete stazu, od starta preko pet kontrolnih točaka (po redu; ako preskočite jednu, kontrolori će vas vratiti natrag) do cilja.

Mjeri vam se vrijeme i boduju vam se odgovori na pitanja na kontrolnim točkama.

Ove je godine novina u tome što vam sve kontrolne točke nisu ucrtane u kartu, nego ćete ih morat pronaći uz pomoć kompasa i naznačenih razdaljina.

Praktični zadatak imat ćete u prvoj od 5 kontrolnih točaka. Tu ćete, kao i sve ostale ekipe utrošiti najviše vremena. U izvođenju praktičnih zadataka bodovat će se i pravilnost postupka pa i na to obratite pažnju.

Na ostalim točkama (koje prvo trebate pronaći) čekaju vas teoretski i neki računski zadaci. Stoga je potrebno da uz sebe imate kalkulator. «APOMENA: pazite na mogućnosti prolaza- ne možete preskakivati ograde već pratite staze ili slobodan prostor.

Odgovore upisujete u svoj radni list, a da ste odgovor upisali zaista na kontrolnoj točki, žigom i potpisom ovjerava kontrolor. Ako ste se zabunili, kontrolor to treba označiti i parafirati. Naknadne ispravke komisija neće uvažavati.

Nemojte zaboraviti tražiti ovjeru (žig i potpis) kontrolora prije nego odete s kontrolne točke. Ukupni broj bodova kojeg možete ostvariti odgovaranjem na pitanja je 50 .

Na startu će se u vaš radni list upisati startno vrijeme i dobit ćete kartu (plan) područja orijentacijskog natjecanja te zračnu snimku istog područja.

1. Pomoću kompasa orijentirajte kartu i odredite glavne i sporedne strane svijeta.

2. Kartu usporedite sa zračnom snimkom turističkog kompleksa Toplica Sv. Martin.

3. Odredite azimut od $110^{\circ}$ i krenite u smjeru azimuta ( cca $150 \mathrm{~m}$ ) prema prvoj kontrolnoj točki - KT1. Rješenja zadataka s objašnjenjima upisani su crvenim slovima, a bodovi uz pojedini zadatak upisani su sivim brojevima. KT 1

ukupno 14 bodova Bodovi po zadatku

1.1. Orijentirajte kartu (plan) i ucrtajte strane svijeta

Priznavana su sva rješenja ucrtana na zemljovidu unutar luka od cca $60^{\circ}$

1.2. Odredite mjerilo vaše karte (plana)

a) 1:200

b) 1:2000

c) 1:20000

d) 1:200 000

U radi list upišite slovo uz točan odgovor

Od pribora su na raspolaganju bili školski trokuti i mjerna vrpca; trebalo je izmjeriti stranicu igrališta i usporediti je s dužinom na karti.

1.3. Praktični zadatak je provedba protokola za mjerenja prozirnosti vode potoka preko kojeg ste prešli.

1.3.1. Prvo trebate definirati mjerno mjesto (define study site)

Prijatelj vam je izmjerio GPS-om koordinate: $45^{\circ} 15^{\prime} 00^{\prime \prime}$

U radni list upišite koordinate u obliku kako ih prihvaća GLOBE baza

$45,2500^{\circ}$, a priznavalo se i $45,25^{\circ}$

1.3.2. Sljedeće je određivanje MUC kategorije

U radni list upišite znamenke MUC kategorije do razine koju možete odrediti.

$M U C=8,2$ (Kultivirano zemljište, Parkovi i igrališta)

Objašnjenje: MUC se određuje na površini homogenog pokrova dimenzija 90 X 90 m. Da bi MUC bio 0 ili 1, trebali bi stajati u šumi, a da bi bila prirodna travnjačka površina, trebalo je stajati u sredini takve homogene plohe dimenzijai $90 \times 90 \mathrm{~m}$.

1.3.3. Odredite prozirnost uzorka vode. Izmjerenu vrijednost upišite u radni list.

Obratite pažnju na postupak jer se i to boduje ! 
Mjerenje pomoću cijevi za prozirnost - ako je sve točno (vidjeti postupak u GLOBE protokolu) nosi 2 boda, za djelomično točan odgovor u rezultatu mjerenja ili postupku, dobilo se 1 bod.

1.3.4. Izmjerite temperaturu vode vašeg uzorka vode.

Izmjerenu vrijednost upišite u radni list.

Obratite pažnju na postupak jer se i to boduje!

Mjerenje pomoću termometra za vodu u metalnom zaštitnom oklopu - ako je sve točno (vidjeti postupak u GLOBE protokolu) to nosi 2 boda. Za djelomičnu točnost u rezultatu mjerenja ili postupku, dobiven je 1 bod. Temperatura uzorka se mijenjala tijekom dana, pa je kontrolor također bilježio vrijednosti, što je kod bodovanja uspoređivano s rezultatima natjecatelja. U postupku je važno izbjeći utjecaj drugog medija ili tijela na termometar, a očitavanje sa skale termometra vršiti se u ravnini očiju.

1.3.5. Uz mjerenje prozirnosti vode procjenjuje se i naoblaka

(2)

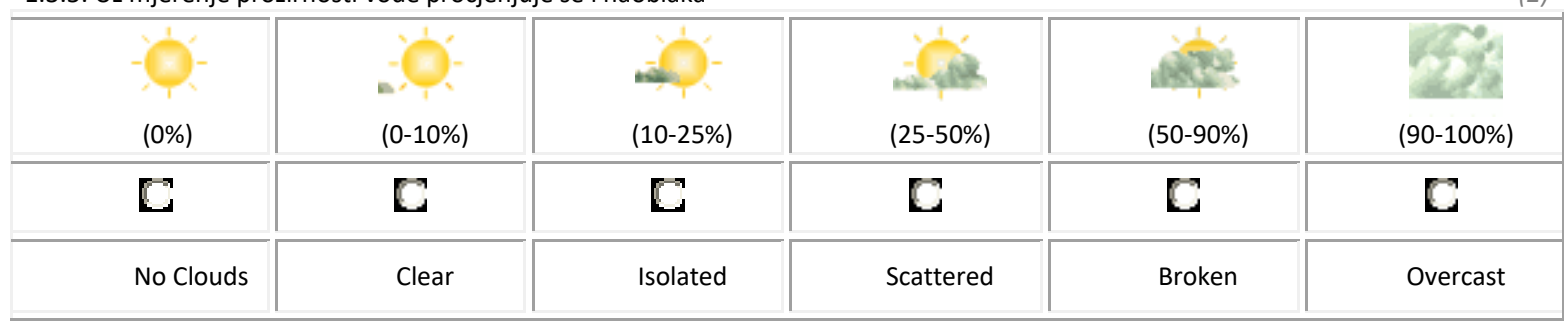

Naziv odabrane kategorije naoblake upišite u radni list !

Naoblaka se tijekom dana mijenjala pa je usporedno s natjecateljskim ekipama, naoblaku procjenjivala profesionalna osoba, koja je kontrolirala uneseni rezultat učeničkog opažanja. Tijekom natjecanja količina naoblake nije prelazila 10\% (Clear) Usporedite još jednom vašu kartu sa zračnom snimkom turističkog kompleksa Toplica Sv. Martin. Pronađite KT2 na karti i krenite ( cca 300 m)

MAPOMENA: pazite na mogućnosti prolaza- ne možete preskakivati ogradu već pratite staze ili slobodan prostor.

2. 1. Usporedi satelitske slike istog mjesta prije i poslije potresa u Japanu. Snimke su komponirane tako da ističu živu vegetaciju.

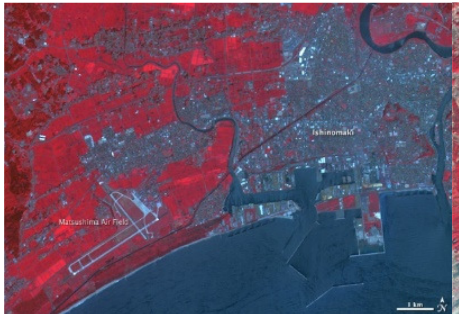

A) Ishinomaki, Satelitska slika prije 11.3.2011.

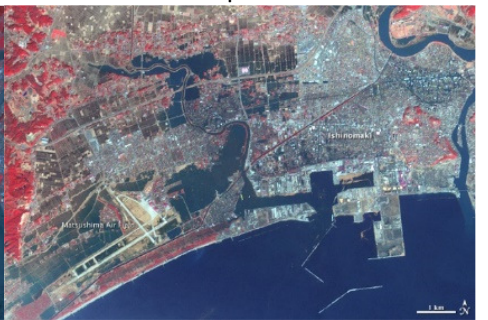

B) Ishinomaki, Satelitska snimka poslije 11.3.2011.

Kakve promjene boja uočavaš na satelitskoj slici B i što te promjene znače?

Pojmove koji nedostaju u tvrdnjama pod a), b) i c) upišite u radni list

Na slici B

a) povećala se površina sive/ svijetlo plave__ boje koja prikazuje porušene dijelove grada,

b) smanjila se površina __crvene__boje, koja prikazuje zelenu vegetaciju

c) Vodene površine su se____ povećale____ (nije se pitalo koje su boje vodene površine na slici, nego što se promijenilo u odnosu na situaciju pod A

2.2.

Za potrebe određivanja vlažnosti tla mjerenjem su dobiveni sljedeći podaci:

Prije sušenja tla

$\mathrm{m}$ (posude) $=12 \mathrm{~g}$

$\mathrm{m}$ (posude $+\mathrm{tlo})=120 \mathrm{~g}$

Poslije sušenja tla

$\mathrm{m}$ (posude + tlo $)=94 \mathrm{~g}$

Račun:

a) Kolika je masa vlažnog tla?

$\mathrm{m}$ (vlažnog tla )= 108g

b) Kolika je masa suhog tla

$\mathrm{m}$ (suhog tla ) $=82 \mathrm{~g}$

c) Kolika je masa vode u tlu

$\mathrm{m}($ vode $)=26 \mathrm{~g}$

2.3.

Navlažimo li uzorak tla, možemo ga ispitati modeliranjem.

Ako je ljepljiv i od njega možemo napraviti sve ove oblike kažemo da tlo sadrži __glinu

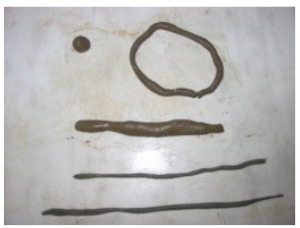


Pojam koji nedostaje upišite u radni list

Uputa za KT 3

Nakon što ste odredili svoje stajalište na karti i zračnoj snimci odredite pomoću kompasa smjer sjeveroistoka (NE) i krećite se (cca 500 m) do KT3.

! obratite pažnju na livadu ( privatan posjed)-krećite se stazom

\section{KT 3}

ukupno 11 bodova

3.1. Kako izmjeriti visinu stabla, kad nam je na raspolaganju samo mjerna vrpca i jednakokračan pravokutan trokut. Čemu će biti jednaka visina stabla?

Bodovi po zadatku

Odgovor upišite u radni list

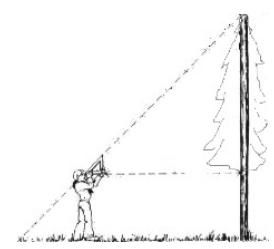

Visina stabla = udaljenost mjeritelja (promatrača) od stabla + visina mjeritelja (promatrača) do očiju je odgovor za 3 boda

Odgovor : $d X \operatorname{tg} \alpha+$ visina mjeritelja do očiju nosi samo 1 bod jer ne uvažava činjenicu da je tg kuta od $45^{\circ}=1$, što u životnim situacijama jako pojednostavljuje mjerenje.

3.2.

Hrvatske vode prikupljaju podatke o vodostaju rijeka. Grafički prikaz pokazuje promjenu vodostaja na rijeci Dravi tijekom 2004 . i 2005. godine.

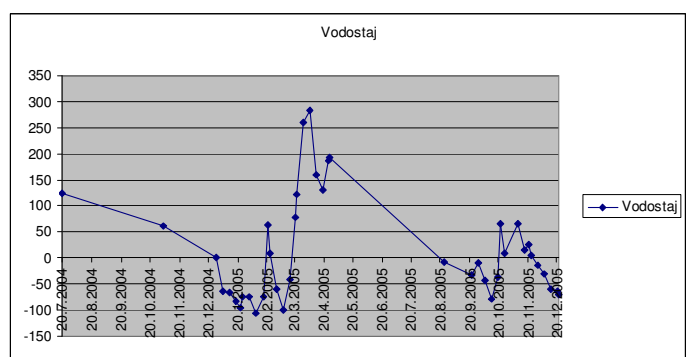

a) Između kojih se datuma očitava najveći i nagli porast vodostaja?

Između 20. i 30. ožujka 2005. (2 boda), raspon 20. 03. - 20. 04. (1 bod)

b) Navedite 2 moguća uzroka takve promjene vodostaja

Uzrok 1: velika količina oborina

Uzrok 2: topljenje snijega

3.3.

GLOBE baza neće prihvatiti podatke koje ste upisali kao što je prikazano na slici. Jedan od ponuđenih odgovora nudi točno objašnjenje.

Note: $\mathrm{pH}$ measurements are only allowed when you have $3.5 \mathrm{~mm}$ or more of liquid.

PH of Rain:
linstrument: pH Meter $v$

$\mathrm{pH}$ of Snow

pH of Snow
hstrument

Snowpac

a/ zato jer niste upisali podatke o $\mathrm{pH}$ snijega

b/ zato jer ste količinu oborine upisali kao broj s decimalnom točkom, a ne decimalnim zarezom

c/ zato jer je količina oborine manja od $3.5 \mathrm{~mm}$

Ta je količina premala da bi se instrumentima koji se u GLOBE mjerenjima koriste išta moglo precizno izmjeriti

Slovo uz točan odgovor zaokružite u radnom listu

3.4

Ako je izlazak Sunca u 7:02 UT, a zalazak Sunca u 17:48 UT, lokalno solarno podne nastupit će u _ 12,25 UT .

$U$ list za odgovore upišite izračunatu vrijednost

KT 4

4.1.

Kakvo je osnovno obilježje vremena u mjestima koja su na karti označena plavom, crvenom i crnom bojom?

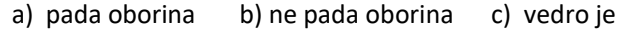

Plavom bojom __ne pada oborina____ Crvenom bojom __pada oborina

U radnom listu upišite slovo uz obilježje vremena uz svaku navedenu boju ukupno 9 bodova Bodovi po zadatku

(6) 


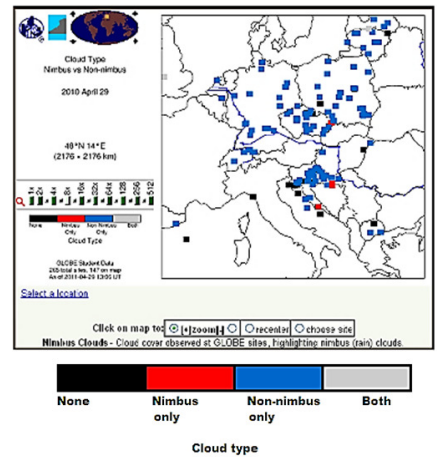

4.2.

Učenici u istarskoj školi u Labinu imaju u GLOBE bazi i podatke za troposferski ozon. Koliko su mjerenja napravili? Očitani raspon vrijednosti unesite $u$ radni list

100 - 125 mjerenja (2 boda) do 150 mjerenja (1 bod)

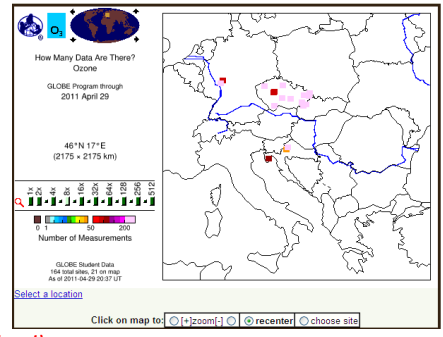

4.3.

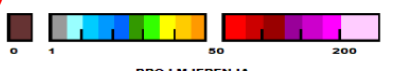

U proljeće pratimo i bilježimo pupanje drveća i grmova.

Ako nam se dogodi da jedan od promatranih pupova otpadne što ćemo upisati pri unosu podataka na www.globe.gov ?

Traženi izraz upišite u svoj radni list

LOST

Uputa za KT 5

Odredite svoje stajalište pomoću kompasa i karte.

Pronađite smjer jugozapada (SW) i krećite se cca 350 m do KT5.

KT 5

ukupno 6 bodova

Bodovi po zadatku

Dobra orijentacija prema uputi na KT4

5.1.

U trenutku dnevnih atmosferskih mjerenja opazili ste gustu maglu koja je zastrla nebo pa je vidljivost u svim smjerovima smanjena na svega pedesetak metara. Što ćete odabrati za vrstu naoblake?

a) nimbostratus

b) stratocumulus

c) stratus

d) altostratus

U radnom listu zaokružite slovo uz točan odgovor

5.2.

Izbacite uljeza među navedenim vrstama oblaka:

a) cirrostratus

b) altocirrus

c) cirrocumulus

d) altocumulus

U radnom listu zaokružite slovo uz točan odgovor

5.3.

Nabavili ste novi min-max termometar, proizvođač je dao potvrdu da je točnost termometra +/- 0,5 oC.

Prema GLOBE protokolu, vaš je plan:

a) Provjeriti točnost termometra prije nego započnete službeno mjeriti i slati podatke

b) Provjeriti točnost termometra prije nego započnete službeno mjeriti i slati podatke i zatim svakih šest mjeseci ponoviti provjeru

c) Nije potrebna provjera, jer postoji potvrda proizvođača o kvaliteti termometra

d) Provjeriti točnost termometra nakon godinu dana

U radnom listu zaokružite slovo uz točan odgovor 


\title{
GLOBE Survey Competition - an important motivating factor in the implementation of the GLOBE Program
}

\author{
Diana Garašić \\ Nova Ves, Zagreb, Croatia, ORCID: 0000-0002-6489-2031 \\ diana.garasic@gmail.com
}

\begin{abstract}
The GLOBE program is an international, science and education program that has been implemented in the Republic of Croatia since 1995 on the basis of an international agreement. Schools involved in the program perform measurements and observations in their environment, in the field of atmosphere, soil, water, land cover and record the results in a common database. The program requires daily atmospheric measurements and students' field trips for measurements and observations in the field of water, soil and cover research. The modernity of GLOBE educational component can be recognized in following features: interdisciplinarity, experiential learning, hands on and field work, the use of modern technology. All this, along with students' teamwork and the skills of orientation in the unknown area, is promoted by the GLOBE Survey Competition, as the part of Annual meetings of GLOBE schools. These meetings represent an opportunity for GLOBE participants to gather, make new contacts and exchange experiences of GLOBE implementation. During 22 years of implementation, these meetings have proven as a significant motivating factor for the implementation of the GLOBE Program.
\end{abstract}

Keywords: survey competition, interdisciplinarity, team work, motivation 